\author{
F.D. Marengo \\ Centre for European Industrial Studies, University of Bath, Bath, England
}

In view of Western interest in learning from Japan, present knowledge of, and British attitudes to, the Japanese economy are critically reviewed through an analysis of press reports in 1977 and 1978. A variety of business people, financial jour. nalists, politicians and other interested parties in Britain, Japan, North America and Europe are quoted on issues such as the relative inferiority/superiority between EEC countries and Japan, attitudes and practices regarding marketing, the 'mysteriousness', cunning and determination of Japanese businessmen, and on differences between Japanese trade relations with the USA, and with EEC countries. Some recommendations are made on ways in which exchange of ideas and goods could be promoted, to mutual benefit of EEC countries and Japan.

S. Afr. J. Bus. Mgmt 1980, 11: 21-27

In die lig van Westerse belangstelling om meer van Japan te leer, word 'n kritiese oorsig gegee van huidige kennis van, en Britse houdings teenoor, die Japannese ekonomie, deur 'n ontleding van verslae in die Britse pers in 1977 en 1978. ' $n$ Verskeidenheid van sakemense, finansiële verslaggewers, politici en ander belanghebbendes in Brittanje, Japan, Noord. Amerika en Europa word aangehaal oor sake soos die relatiewe meerderwaardigheid/minderwaardigheid tussen EEGlande en Japan, houdings en praktyke wat betref bemarking, die 'geheimsinnigheid', geslepenheid en doelgerigtheid van Japannese sakemanne, en oor verskille tussen Japannese handelsbetrekking met die VSA, en met EEG-lande. 'n Paar aanbevelings word genoem, oor maniere waarop wisseling van idees en van goedere bevorder kan word, tot wedersydse voordeel van EEG-lande en Japan.

S.Afr. Tydskr. Bedryfsl. 1980, 11:21-27

F.D. Marengo

Centre for European Industrial Studies, University of Bath, Claverton Down, Bath BA2 7AY, England

Was Visiting Professor, Institute of Labour Relations, University of South Africa, P.O. Box 392, Pretoria 0001, South Africa
Western opinion has lately begun to take a more positive approach to Japan's economic prowess. We seem now resolved to form our attitudes $v i s-\grave{a}$-vis this country mainly with reference to the question, what can we learn from it.

Learning, however, comports the modification and often rejection of old habits and ideas as well as the acquisition of new ones. Indeed, we must first unlearn in order to learn. To this extent, we really should ask ourselves the question, what do we need to unlearn about Japan if we want to learn from her.'

Our first task must therefore be to critically review our present knowledge of Japan and make explicit the factors upon which we have built it. This paper wants to contribute to such a task by exposing some of the views currently held by British people with regard to their country's trade relations with Japan. It has tapped these views through an analysis of the Press from February 1977 through April 1978. ${ }^{2}$

\section{Inferiority - Superiority}

An American cartoon a few years ago portrayed $\mathrm{Mr}$ Richard Nixon, then President of the United States, sitting at his desk and trying to appear casual, but also showing by the expression on his face, that he was well aware of having played a 'dirty trick' on the person who soon was going to sit (or stand?) in front of him: his was the blend of denied and admitted guilt we put up to someone who, we know, is rightly cross with us. Mr Nixon was preparing to receive the redoubtable Mr Takeo Fukuda, then Japanese Minister of Foreign Trade, who, with a well adjusted karate blow, was smashing his way through the door into the room. Mr Nixon, hearing the fracás, exclaimed: 'Come in, Mr Fukuda!' We Westerners (the Britons) do feel guilty. They (the Japanese) are strong and we are weak, that is it. Their only fault is to be . . . superior. Better, it is not they who are superior, it is we who are inferior. We have only ourselves to blame.

Do we, however, actually blame ourselves? Occasionally we do. More often, however, we make them blame us and tell us: 'It is not we, the Japanese, who are superior, it is you, the Westerners, the Europeans, the Britons, who are inferior'. Thus, Richard Harris titled one of the articles he wrote for The Times, 'The Japanese see a European failure in their success'.

Some of them (those Europeanized?) oblige. One Mr M. Sato, for instance, wrote to the Editor of The Times: 
'Sir, Your headlined article of Monday this week mentioned the need of the Japanese to buy more from Europe. On the contrary, it is surely the need of the Europeans to sell more to Japan that should be under consideration."

Mr Sato went on:

We have a large consumer market ... but it is also a market that takes considerable study and hard work to achieve profitable penetration. The Japanese worked hard and studied the European and American markets to obtain a foothold, and perhaps you would allow a humble Japanese to express the opinion that it is about time the Europeans did the same.

And, rubbing salt in the wound, Mr Sato concluded: 'The Americans seem to be achieving success here and there will be little excuse in the future for European failure'. So, we are inferior because we do not try hard enough, whereas they work very hard. We have lost the 'guts' to fight and win. A significant slip placed Mr Sato's letter under the wrong headline, 'Sharing out the spoils of business', instead of the correct one, 'Selling Europe's goods to Japan'.4

R. Harris witnesses that this opinion, that we are lazy, is by no means peculiar to Mr Sato, but widely held in Japan. 'Can Western exporters break into the Japanese market?', 2 he asked his hosts, and reported:

The Japanese answer is: Yes, if they take the same trouble with our market that we do with theirs . . . How many businessmen coming to Japan from Britain or her European partners spoke Japanese compared with the number of Japanese going to Europe who spoke English, say? How many understood the working of Japanese society $?^{2}$

Curiously, if we make them say that we are inferior, according to some evidence they try to make us confess the same: for instance, that we are unreliable suppliers. A year ago, the Japanese Information Service put out an advertisement in the form of an interview of Dick Wilson by Susan Smith. In the course of this interview, Wilson declared: 'They are sophisticated people with decided tastes and preferences. They want cars or TV sets that work reliably, look nice and don't cost too much - and they want them now, not in six months' time . . . [They do things] more cheaply and efficiently than we do.'s

Feeling inferior, we are afraid lest they may hold us in no account, indeed in contempt. Again, we do not openly say this ourselves, but look for signs on their side which could confirm our fears and unfailingly find them, almost to our relief. According to a newspaper report:

Speaking at a dinner given by the Harvard Club in Tokyo, Mr [Nobuhiko] Ushiba [Japanese Minister for External Economic Affairs] said the French elections were 'casting a long shadow on Europe'. Germany was 'suffering from terrorism and espionage' and the British Government was stumbling from one lost vote to another in the House of Commons. In these circumstances, $\mathrm{Mr}$ Ushiba said, "we [we, Japanese, or we, Japanese and Americans?] really cannot expect much from Europe at this time'. He also gave a clear warning that the EEC could not expect an overnight solution to its $\$ 5,000$

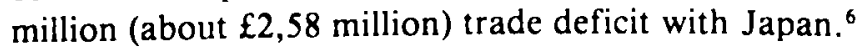

The Times correspondent significantly commented as follows: 'Mr Ushiba's remarkably undiplomatic outburst has more than confirmed the fears of many EEC officials that the reflation measures announced by the Japanese are mainly designed to help American rather than EEC exporters.' (my emphasis)

Three days later, this same correspondent (Peter Hazelhurst) passed on to his readers another piece of information (confidential, this time) that again should have 'confirmed their fears'. 'A highly reliable informant within the Japanese foreign ministry - he wrote - told me: 'We will not make similar concessions to Europe. It does not have the political or economic weight to warrant such a step'.?

The fear of being held in low esteem implies the belief that we are on the verge of losing our old status and being relegated to a minor one, if this has not already happened. Specifically, we believe, first, that the Japanese do not put us 'on a par' with the United States and, secondly and more painful, that the Japanese are taking over our privileged position to the right side of the United States. Again, we ask them to remind us of the unpleasant reality. Thus, with regard to the first point, Mr Ushiba, in the above-mentioned 'undiplomatic outburst', 'also gave a clear warning that the EEC could not expect . . . to be treated by Japan on a par with the United States'. ${ }^{7 \text { p.20 }}$

As for their attempt to dislodge us as confidant of the United States, R. Harris was under the impression of having been conveyed this message in Tokyo: 'Who do these Europeans think they are? They are of no importance in a world dominated by the United States and ours is the economy second to the United States in its world importance. We are partners of the United States and intend to remain so'. ${ }^{8}$

Who is, however, to judge? Who runs the club and who applies for membership? Therefore: Shall we let them in or shall we keep them out, in the cold? Of course, we are too civilized to say (loudly) so. We make them say (or, better, feel) these things. They believe (or, rather, we believe that they believe) that we do not regard them as our equal. 'Would they [the Westerners] have dropped it [the bomb] on the Germans?' ${ }^{3}$ According to R. Harris, 'the question is inescapable. One looks around and imagines every Japanese saying it to themselves'. ${ }^{3}$

Indeed, there is more to it. They believe that we do not regard them as our equals in trade matters. They believe that we think that, if they have flooded our markets with their goods, they have not done so by playing a fair game. 'That is what the Japanese are thinking about the trade imbalance now,' Harris writes, 'would they [the Europeans] have made such a fuss or issued the same ultimatums about an imbalance of German or American exports?'3

It seems, however, that a true Japanese buinessman, like Mr Akiro Norita, would put it in a slightly different way and would not refrain from 'humbly' suggesting that we are ... fool who fool ourselves. Interviewed by Simon Scott Plummer, the Chairman and co-founder of Sony declared: 'They [the Europeans], regard Japan as far away, the land of Mount Fuji and the geisha girls. 
That's why, when Japanese industry makes itself felt in Europe, some people feel that a strange people is invading. That is a pity [presumably, for the Europeans]."

Yet, we do not pause, but go even further and believe that they feel themselves to be altogether inferior to us. Therein, their (as seen by us) constant need to prove to us their worth, so that we may be moved to treat them as our equals. R. Harris explains:

The historical context in which all Japanese see their relations with the Western world dates from the second half of the 19th century, with Japan's turnabout from being a closed country to one seeking equality with the West in military and industrial power. Many of the ideas which took shape then still govern Japanese thinking now. ${ }^{3}$

This need of theirs entails (always in our view) another one: they feel as though they ought to prove that they do not need us. Harris reflects:

Equality with the West meant industrialization, meant Japanese ability to make anything they needed themselves and consequently made the import of manufactured goods a reflection on their ability and thus to be avoided. To import such goods meant that Japan was still lagging behind. ${ }^{3}$

They refuse to import not all our goods, though. They still acknowledge the excellence of our luxury products and, as a sign of 'humble respect' ... inflate their prices.

Another belief dating from the 19th century, Harris writes, was that imported books - Hakurai, the seaborne goods - were by nature exotic, rare and for the few. Foreign goods were first class and thus very expensive; indeed, authentic only if they were expensive and thereby endowing the purchaser with status. That this attitude still survives was amply borne out from present evidence. British goods on sale in Japan now, from Rolls Royces to marmalade, were uniformly three or four or even five times as much as their British prices. ${ }^{3}$

Another (luxurious? superfluous?) item they recognize our superiority on is culture. Harris informs us:

[There is a] flood of Japanese university students who visit European countries [invisible earnings, for us, investment for them] . . . [To this, may be added] Japan's own uninhibited imports from the West - books, music, art, fashion, food - Tokyo is full of it. Ask questions about the Japanese as wholesale importers of overseas culture and the reply will be that they have always been importers. $^{8}$

Yet, if the range of products we can sell to them goes 'from Rolls Royces to marmalade', we cannot derive much hard cash benefit from it. According to Peter Jay, who took up his appointment in Washington mainly to sell our goods there, 'there is a limit to the amount of Scotch Whisky and Oxford Street goods which they [the Japanese] can buy from less technologically advanced countries like Britain'. ${ }^{10}$ The Chairman of the Japan
Trade Advisory Group of the British Overseas Trade Board, Mr Geoffrey Nichols, called such beliefs, 'myths' (which, however, does not detract from their being real) and claimed that they were 'plain nonsense'. ${ }^{10}$

More smartly, the Japanese suggest that we can turn myths into assets. In the advertisement mentioned above, the Japanese Information Service made $\mathrm{Mr}$ Wilson argue:

British product carries such prestige among the Japanese. The prestige is something we have inherited from the past and we are lucky that it survives. But why not put it to use for mass distribution instead of letting the rich élite in Japan monopolize it?"1

Such suggestions, however wise, fall on deaf ears. We believe that we can get nothing out of our superiority. Indeed, our superiority plays into their hands, whereas their parallel inferiority hurts our interests. For instance, it is widely held that, against our sophisticated and smooth distribution system, the Japanese possess 'an overmanned, inefficient and underdeveloped service sector (both public and private)'.$^{12}$ No surprise, therefore, that the Japanese find it easy to flood our markets, whereas we constantly stumble on bottlenecks in theirs.

The overall picture is, thus, the following: our superiority brings no tangible benefit to us (indeed, some advantage to them), whereas they exploit to the full their superiority. Our inferiority makes us ill equipped to cope with them, whereas they have turned their inferiority into an asset.

\section{Force}

By force, they knock down the obstacles they meet (and we erect) in their path. If we keep the door shut on them, they will smash it (but didn't we do the same last century?) and once in, our shy smile is no match to their glittering teeth (again, were not the roles reversed in a not too distant past?). The cartoon described in the beginning impressively shows it.

'Japan is a country where nationalist emotions have been repressed for the last three decades, ${ }^{3}$ R. Harris points out. Now, they find expression, at long last, in a huge trade surplus.

We, moreover, know about their force of character to hold their steam, without letting it out in little bursts, and then vehemently expel it all, when the opportunity occurs. I often heard the story that in the toilets of Japanese workshops are hung the dummies of the various bosses. Workers, when they feel they are bursting, are allowed to go there and do all sorts of things to these dummies. Appropriate weapons are provided to them. We now find ourselves in the clothes of these dummies; we are the handy victims on whom they discharge their repressed aggressiveness.

Vehe victis and all the more so, since we know that they are ruthless. According to The Times Parliamentary Report:

Mr Douglas Hoyle, Labour MP for Nelson and Colne, yesterday attacked Japanese 'arrogance' for refusing to give any commitment to restrain future exports [of cars] to Britain ... Failure to introduce firm quotas would 
only hasten the demise of the United Kingdom homebased car industry. ${ }^{13}$

Mr Hoyle's word was, however, inappropriate: it is not the turgid but unconsequential 'arrogance' that we fear from them, but their utter pitilessness.

With them, as Mr D. Hoyle seemed to imply, it is a male game that we must play. Mr Michael Montague wrote to The Times, 'Regrettably, knowing the Japanese mind, I must forecast that we will only get equity if we issue an irrevocable ultimatum about all trade, as we appear to have just done with motor cars. The Japanese understand action, not psychology'. ${ }^{14}$

According to a newspaper report, Britain and France are ready to jump into it, without taking any precaution, any shelter. They want a straight deal with Japan (whom they do not mention by name!), face-to-face. Or do they? the report reads, a bit curiously: 'One of the main demands made by both is that they be allowed to take discriminatory action against a foreign supplier when the import surges disrupt (their) domestic markets. is (my emphasis)

The image that these resolves evoke is the game of poker (which cannot be played by two). A curious game of poker, though, where bluffing is ruled out, because it won't do. The Economist warns: 'Japan is expert at working out when its trading partners are bluffing. America's trade negotiator, Mr Robert Strauss, accepted in Tokyo nearly the same package he had earlier dismissed in Washington as unacceptable. Lesson: be tough, don't bluff.' 12 p.90

And if it were they who bluff? Sir Roy Dennan, the EEC Commission's Director General for External Economic Affairs, promised: don't worry, that won't do either. On his way to Tokyo, he was reported as having declared, with much bellicosity, 'that the EEC was not going to be fobbed off with an "empty statement of generalities". It would continue to insist on a "substantive and meaningful statement", even if that meant a breakdown of talks. ${ }^{\prime 16}$

The trouble is that, in poker, if you rule out bluffing, you have got to play only with your cards and you win only if you have good cards. At the end of the visit to Tokyo by the 'top brass' from Brussels, The Economist commented:

Japan called the EEC's bluff last week and got $\mathrm{Mr}$ Willhelm Haferkamp, the EEC Commissioner in charge of external affairs, to sign a woolly joint communiqué. The text eventually agreed on gives Europe less than the Americans got in January . . . High marks in the talks must go to the tough Mr Nobuhiko Ushiba, Japan's Minister for External Economic Affairs. ${ }^{17}$

After all, it is a commonplace to say that they have 'poker faces'!

\section{Mysteriousness}

Indeed, they are unyieldingly mysterious. We find it difficult to penetrate their business practices, and natural barriers like distance and language, make things all the more difficult for us. The Parliamentary Under-Secretary of State for Trade, Mr Michael Meacher, rightly pointed out that their "language and customs are still unfamiliar to many exporters'. ${ }^{18}$ His associations were, however, curious (that is, significant). Mr Meacher's whole sentence read: 'The Japanese market calls for high standards of quality, delivery and reliability [all things mysterious to us?] and its language and customs . . ${ }^{\text {is }}$

A Japanese (businessman?) living in London, $\mathrm{Mr}$ Mosahiro Sugita, acknowledges that distance and language are drawbacks (for us). He, however, does not allow us to freely use them as excuses for our failures and, indeed, does not refrain from reproaching us. He wrote to The Times: 'The sheer geographical distance and possibly the language barriers have tended to give rise to many misconceptions in Europe and particularly in Britain about the regulations and business practices of Japan. ${ }^{19}$ (my emphasis)

When we claim that they are mysterious, we have, consciously or unconsciously, two things (complaints) in mind. First, they do not seem to contract our illnesses. Secondly, they do not play according to the same rules as we do. Japan is a nation, The Times correspondent wrote from Tokyo, 'where loyalty to the company is so strong that many workers normally strike during their lunch break'. ${ }^{14}$ p.1

R. Harris further articulated the point:

Japan is a country in which nation and society are one and in which national objectives - sensed and diffused rather than transmitted from on high - remain the core of the social consensus ... They give such an impression of united front in any trade negotiations that they have been likened by Europeans to totalitarian states. ${ }^{3}$

The difference, Harris could have added, is that the European totalitarian states were those among us who took an overdose of medicine and killed themselves, whereas the Japanese have never actually been infected.

The able writer who drafts the leaders for The Guardian, elaborates on the point still further, so as to make it appear that they are sick and we are healthy (although the revised health bulletin admittedly had no effect on the trade balance). He argues:

Precisely because Japanese industrial development has had so little need to pay attention to social costs, it has been able to out-invest and out-export even the more efficient Western European countries. Balanced Japanese economic development is important for the rest of the world if destabilising trade surpluses and (in Europe) deficits are to be avoided. More balanced economic development in Japan must involve both more welfare spending and better regional development. ${ }^{20}$

Another thing we cannot stomach is that they want to play the game according to their, instead of our, rules. Our implicit claim is that our rules are better than theirs. Do we, however, understand their rules? Occasionally, we claim we do and reject them as ungentlemanly. The Economist, for instance, wrote:

Outsiders have five short-hand reasons for Japan's trading prowess - all loosely grouped under the heading of 'they-play-to-different-rules': subsidized exports; an undervalued yen; a protected home market; low profits 
and low-marginal-cost-exports (or indeed, dumped ones); low foreign and defence spending. ${ }^{12}$

In the same stream of thoughts, the former leader of the Opposition, Mrs Margaret Thatcher, while in Tokyo, coined, in the best tradition of politicians, the 'catch all' formula: 'I believe in free trade, but fair trade'. ${ }^{21}$

The Secretary of Trade, Mr Edmund Dell, in Tokyo on Mrs Thatcher's heels, 'described as "curious"'[their] approach towards the principles of free trade. Japan's attitude was that if you decide to invest in an area [like car manufacturing?] you do not import.' 22 The Times correspondent explained that $\mathrm{Mr}$ Dell made his remarks 'in answer to a Japanese claim that the trade gap between the two countries had developed because Japan, unlike the United Kingdom, had injected capital investments into projects to increase export productivity' ${ }^{22}$ In the light of this clarification, someone could find Mr Dell's remarks rather 'curious'.

If we find Japan's rules 'unfair', are we ready to commend our own rules as fair? Melvyn Westlake has described as follows our more recent version of the 'gentleman's agreement' specifically devised for Japan.

It is because of the difficulties involved in taking emergency action under Article XIX [of GATT] that the United States and the EEC have increasingly resorted to strategies outside of the GATT to restrict imports. These strategies include 'voluntary export restraints' and 'orderly marketing arrangements', which are extorted from Japan and low cost developing countries through a process of political arm-twisting and commercial threats. ${ }^{8 \text { p.21 (my emphasis) }}$

These are our rules at governmental level. What about our rules at business level? Our mind immediately goes to the 'Lockheed scandal', and we are afraid that the Japanese mind may do so too. On the same day on which it published M. Westlake's article, The Times received the following correspondence from Tokyo:

[Japanese] officials pointed out today that the Government is considering the idea lof buying an unspecified number of A-300 airbuses from Europe] . . . Japanese leaders have constantly reminded visiting European delegates that in the light of the recent Lockheed aircraft scandal, the Government can do little to influence the orders of Japan's three major airlines. ${ }^{8 \text { p. } 19}$

Often, however, we complain that we cannot understand their rules. For instance, the political columnist of The Times, David Wood, wrote, not without hidden thoughts and contradictions:

To start with, it is not easy in a few days for Western politicians to be sure where the front of power lies in Japan [in order to bribe the right people?] and who settles the economic and trading policies it pursues. Japan is run as a kind of corporate state [in which case, power would be quite formally allocated and it should not be difficult to understand how the system works] wherein, unlike the United Kingdom, big industry and the big banks are closely intermeshed with the Government. ${ }^{8}$
Do they understand our rules? They have learnt our economic tenets, which we have now unlearnt and they reteach us. Mr Akiro Norita, for instance, in the interview mentioned above, lectured us on investment and marketing and their (medium term) features:

'We have invested a large amount of money, time and effort to develop markets, setting up sales corporations, studying each country's tastes, regulations and safety standards. For the first few years we did not make any money. That is investment . . . We want the European to understand how hard Japanese industry has worked. The same sort of effort needs to be made by European companies in Japan'.?

\section{Cunning}

In this respect, the factors that we claim make it so difficult for us to penetrate their mysteries, do not apparently make it difficult at all for them to penetrate ours. Thus, they have learnt the English language. As for 'distance', The Economist once pointed out: 'Distance never deterred Japanese exporters: it seems that somehow Japan is farther from Britain than Britain is from Japan'. ${ }^{12 \text { p.86 }}$

They are, indeed, tricky (which implies that we are, instead, a bit gullible). They are cunning and certainly clever at treading that narrow line that runs between legality and illegality. The former Canadian Ambassador to Japan, Mr R.P. Bower, authoritatively confirmed an opinion that many of us share, when he wrote to The Times with regard to Japan's import restrictions:

When Japan has restricted importation of many manufactured items from abroad, the local manufacturers, because of their virtual monopoly of the home market, have been able to make enough money on domestic sales to finance dumping overseas and so to secure the economy of large scale production. ${ }^{23}$

No less authoritatively, a leader of The Times argued the same point when Japan liberalized imports:

'Japan can rightly point out that it has removed the tariffs and barriers which made it so difficult for foreign manufacturers to sell in the Japanese market. But it has done so only after years of protection which have been used to build up an industry strong enough to compete with any in the world'. ${ }^{24}$

The leader duly uncovered an actual piece of Japanese trickery:

The SMMT (Society of Motor Manufacturers and Traders) released figures in London which cast grave doubts on the sincerity with which past undertakings by Japanese manufacturers have been observed... The breach of the promise not to increase Japan's share of the British market during 1977 was even greater than appeared from the initial official figures ... It now seems clear that the registration of some Japanese cars was postponed from December to January, thus artificially decreasing the figures for $1977 .{ }^{24}$ 
We are haunted by their trickery.

When, some 20 years ago, a colleague of mine was a school pupil, his teacher of geography who must have then carried for him the same authority that a leader of The Times does now, told his class that the Japanese had built a town called USA, so as to be able to send abroad goods 'made in USA'. Probably swayed by the same idee fixe, recently the Financial Times headlined, 'Victor links with Thomson-Brandt' and only later in the article unveiled 'a similar agreement with Norddeutsche Mende'. ${ }^{16}$ Yet, as the article detailed:

The [video-tape recorder] sets will be marketed in France and in any other countries using the SECAM broadcasting system where Thomson-Brandt maintains distribution channels. The agreement with Norddeutsche Mende covers sales in European countries using the PAL broadcasting system, including West Germany and the UK. ${ }^{16}$

However, Thomson-Brandt sounds more English than Norddeutsche Mende.

A particular feature of their trickery is their deviousness, their winding way to get to target. Directly or indirectly, they enlist the support of third parties to assail us (with their goods). The Labour MP, Mr Ronald Atkins, recently told Parliament: 'Japan has built up her industrial strength with the help of protectionism, and now in Ireland is preparing to flood the British market with commercial road vehicles.' ${ }^{25}$ Mr Michael Meacher, Under-Secretary for Trade, conceded 'He is right'. ${ }^{25}$

Indeed, they know how to manoeuvre our friends and allies against us, whereas we cannot do the same against them. Furthermore, the behaviour of our allies, even when not explicitly co-ordinated by the Japanese, plays into their hands. During the same Parliamentary 'Question Time', another Labour MP, Mr Roderick MacFarquhar, pleaded with Mr Meacher: 'Would he undertake to investigate whether there are impediments to Japanese car imports to France and Italy which do not exist in this country and ry to make them remove them.' ${ }^{25}$ Mr MacFarquhar was implying that the Japanese dispatched to us the cars they could not dispatch to France and Italy, and suggesting that these two countries, as good allies of ours, should instead suffer with us the scorches of the Japanese onslaughts.

To be truthful, Mr Meacher was more hopeful with regard to the positive support we could get from our Community friends, when he argued: 'Certainly the opoprtunity of gaining an improvement in the situation from the Japanese is aided by the fact that the United Kingdom is negotiating through the EEC., ${ }^{25}$ Although he also cautioned: 'Providing, of course, we can get the agreement of other member States in the first place, which is not by any means always the case. ${ }^{25}$

Soon after these exchanges in Westminster, a top level Community mission visited Tokyo for negotiations. The outcome of those negotiations was such as to realize our fears and quench our hopes. The Economist, for all, gave 'high marks in the talks ... to the tough Mr Nobuhiko Ushiba, Japan's Minister of External Economic Affairs, who exploits divisions in the Community only too well., ${ }^{17}$

\section{Possible approaches or solutions}

Either by reflection or, indeed, by natural inclination, we too are (or try to be) ingenious. Unlearned opinion believes that it is after all easy for us to defeat Japanese callousness. For instance, they do not contract our illnesses? It is a matter of increasing their exposure. Thus, one Mr Harold Burnham wrote to The Economist:

There must be something we can export profitably. Perhaps, it might be our trade union expertise in exacting a larger share of the industrial cake? If we could teach the Japanese worker how to grab more, Japanese production costs would rise towards our own and our goods would become more competitive. Why not send an invitation to 100 Japanese trade unionists to spend a year in Britain, seconded to major unions, in order to study their methods. The cost could be shared in equal proportions by the Government, the TUC and the CBI. ${ }^{26}$

Likewise, Mr B.T.R. Thorne, Secretary of the Daimler and Lanchester Owners' Club explained to the Editor of The Times how their camouflaging could be easily unmasked. (Since they copy our models: their cars should have ... slant lamps!)

He wrote: 'One item that was very apparent in a recent opinion poll was the percentage of car owners who did not know they were driving a foreign car, let alone Japanese ... In the textile retail trade all garments are now marked with the country of origin or manufacture. Why are cars not marked in a similar manner? The car manufacturers already use large quantities of bras regalia, so a similar sized "Made in Japan" or "Made in West Germany" will surely be no hardship or detract from the styling of the boot. I feel certain that if this were made compulsory far more people would realise what a foreign car is, and then perhaps they would buy British.'27

Learned opinion is more sophisticated but no less peremptory. The Economist stated: 'There are two obvious ways in which the [Japanese] current surplus can be used to increase Japanese exports of capital, and to raise the amount of aid of various kinds Japan offers to less developed countries.'12 pp8s-86 (my emphasis)

Mr Alan Williams, the Minister of State for Industry, recently went to Tokyo to convince the Japanese about the wisdom of the first 'way'. He 'told the Keidanren (Japan's CBI) that investment in lucrative overseas markets [that is, in Britain] would be one means of reducing the country's trade surplus." ${ }^{28} \mathrm{Mr}$ Williams came back with the impression that the mission had been successfully accomplished and it remained for him to find the formula to express it. Which he immediately did, as follows: 'They are moving into international production rather than international selling. ${ }^{29} \mathrm{Ah}$, if we had found the formula before!

Why not, however, combine together The Economist's 'two ways'? At EEC level (did it need the Latin mind in order to contrive it?) we did so and threw in two plans, a general and a specific one. Following the specific proposal, 'Japan might purchase an unspecified number of A-300 airbuses from Europe and attempt to lease the aircraft to South-east Asia nations'. 8 p.19 
It is, however, the general plan that best extols all our ingenuity (to get the others to solve our problems). True, the plan requires the cooperation of third parties (often unfriendly to us), and Japan itself; but both are taken for granted. That staunch supporter of untrammeled free trade, The Guardian, described the plan under the title, which lined a boisterous term alongside a technical one, 'Radical new strategy for OPEC-style recycling to prevent trade war.' Subtitle: 'Japan urged to fund EEC exports ${ }^{30}$ It wrote:

The Common Market is to adopt a radical new strategy to help deal with the massive Japanese trade surplus which is threatening to lead to import protectionism in Europe ... The Nine ... want Tokyo to use the Japanese surplus to finance Europe's deficit as well as the need of developing countries. The new approach would treat the Japanese trade surplus, at least in part, in the same way as the surplus of OPEC oil producing states. In other words, it would be 'recycled' to where it could to be rapidly and completely eliminated. The Japanese balance of payments surplus, which some fear could total 18 billion dollars this year, could be used to directly finance the deficit of EEC countries. But an alternative also being studied, would involve Japan drastically increasing aid to developing countries to be used to buy exports from Western Europe. At present most of Japan's modest overseas aid finds its way back in the purchase of Japanese exports. If, in future, it could be 'tied in reverse' to the exports of European countries which have a deficit with Japan, world [i.e. our] trade could receive a significant boost. ${ }^{30}$

Indeed, pro bono omnium. The leader of The Guardian, enthusiastic about the plan, spelled out the advantages that would accrue to the parties to it, while emphasizing its ingenuity (in its comments, the adjective 'radical' gives way to the more appropriate 'imaginative').

Why not tell Japan (and other chronically surplus countries) that they should use thier reserves to increase the funds of multilateral aid organisations? Nearly all the money which was lent to poor countries would serve to increase demands for imports. A condition of the aid should be that imports should not be bought from surplus but from deficit developed countries.

This would still mean more economic resources for the poor. It would indirectly help Europe to close its overall payment deficit. And it would be a better option for
Japan than the unpopularity its present position involves, which could lead to it being excluded from European markets ... Without some imaginative new initiative, Western economic 'leadership' is likely to prove as ineffective in future as it has been in the recent past. ${ }^{31}$

\section{Acknowledgement}

I would like to thank Professor Nathan Leites for his comments.

\section{References}

1 DE BETTIGNIES, H.C. Can we learn from Japan? Chelwood Rev. 1978, 4: $38-45$.

2 LEITES, Nathan. The new economic togetherness. American and Soviet reactions. The Rand Corp.: Monica, California, 1973. (Professor Nathan Leites made in the early 70 s a study of the opposing camps' views about East-West trade relations, to which this paper is intellectually indebted.)

3 The Times, 24 February 1977, p.14.

4 The Times, 8 February 1978 , p.18.

5 The Sunday Times Magazine, 10 April 1977, p.13.

6 The Times, 14 February 1978, p.20.

7 The Times, 17 February 1978, p.17.

8 The Times, 3 March 1977, p.14.

9 Europa, April 1978, p.1. In: The Times 6 April 1978.

10 The Times, 24 March 1977. Quoted by Mr Geoffrey Nichols, in a letter to the editor.

11 The Sunday Times Magazine, 10 April 1977, p.15.

12 The Economist, 18 March 1978, p.85.

13 The Times, 10 February 1978, p.18.

14 The Times, 15 March 1978, p.24.

15 The Times, 10 April 1978, p.17.

16 Financial Times, 21 March 1978, p.5.

17 The Economist, 1 April 1978, p.49.

18 The Times, 9 January 1978, p.17.

19 The Times, 3 April 1978, p.18.

20 The Guardian, 29 March 1978, p.12.

21 The Times, 19 April 1977.

22 The Times, 21 April 1977.

23 The Times, 19 March 1977.

24 The Times, 9 February 1978, p.17.

25 The Times, 14 March 1978, p.10.

26 The Economist, 21 May 1977, p.6.

27 The Times, 22 February 1978, p.22

28 The Times, 4 April 1978, p.18.

29 The Times, 11 April 1978, p.19.

30 The Guardian, 27 February 1978, p.14.

31 The Guardian, 27 March 1978, p.10. 